\title{
IN THE SHADOW OF THE LEGISLATURE: THE COMMON LAW IN THE AGE OF THE NEW PUBLIC LAW
}

\author{
Daniel A. Farber* and Philip P. Frickey**
}

It is a commonplace that we live in a statutory era. A century ago, statutes were considered intrusions into the pristine order of the common law. ${ }^{1}$ Today, legislatures are the primary source of law, and the statute books grow exponentially. Nevertheless, the common law has shown great vitality. In the past thirty years, for example, the law of products liability has undergone explosive growth. ${ }^{2}$ The common law has also retained its ability to respond to changes in social values. In contracts, old common law doctrines like "employment at will" are under increasing attack. ${ }^{3}$ In property, long-established rules are being challenged in the name of new social values. ${ }^{4}$

There is nothing new about change in the common law. But in an era of statutes, the role of the common law in formulating social policy has become problematic. Arguments for innovation in the common law are almost always challenged on the ground that the legislature, not the court, is the proper forum in which to argue for reform. Existing common law rules may be challenged for reposing too much policymaking discretion in the courts. ${ }^{5}$

In this essay, we explore how modern common law judges should view their role vis-à-vis the legislature. We suggest that the perspec-

* Henry J. Fletcher Professor of Law, University of Minnesota. B.A. 1971, M.A. 1972, J.D. 1975, University of Illinois. - Ed.

** Professor of Law and Julius E. Davis Professor of Law for 1990-1991, University of Minnesota. B.A. 1975, Kansas; J.D. 1978, University of Michigan. - Ed. We would like to thank Bill Eskridge and Nick Zeppos for their helpful comments on earlier drafts. We would also like to express our appreciation to the participants at the October 5-6, 1990, Conference on the New Public Law at the University of Michigan Law School.

1. See, eg., W. Eskridge \& P. Frickey, Cases \& Materials on Legislation: Statutes and the CReation of Public Policy 242 (1988); Grey, Langdell's Orthodoxy, 45 U. PitT. L. ReV. 1, 33-35 (1983).

2. See, eg., Prosser \& Keeton on Torts 677-724 (5th ed. 1984).

3. See, e.g., E.A. FARNSWORTH, FARNSWORTH ON CONTRACTS $\S 7.17$, at 320-25 (1990); St. Antoine, A Seed Germinates: Unjust Discharge Reform Heads Toward Full Flower, 67 NEB. L. REV. 56 (1988).

4. See, e.g., Babcock \& Feurer, Land as a Commodity "Affected with a Public Interest", 52 WASH. L. REv. 289, $295 \mathrm{n.33}$ (1977) (discussing judicial changes in landlord/tenant law); Freyfogle, Context and Accommodation in Modern Property Law, 41 STAN. L. REV. 1529, 154044 (1989).

5. We develop these themes in Part II infra. 
tive of the "New Public Law," as we conceptualize it, is surprisingly helpful in considering this problem.

In Part I, we briefly summarize two important aspects of the New Public Law: republicanism and public choice. We then address an obvious objection to our project - that our topic relates to private law, and is therefore outside the purview of the New Public Law. Part II turns to important questions about the relationship between statutes and the common law: When should statutes be considered to displace existing common law remedies? In considering a possible reform in the common law, when should a court defer to possible legislative action? In analyzing these questions, we examine two lines of cases, one dealing with tort actions in admiralty, the other with the federal common law of nuisance. These cases exemplify two possible judicial responses to the intrusion of statutes into common law adjudication. Some opinions take statutes as a signal to abandon the common law, but common law can be a valuable adjunct to legislative policymaking. Part III contains some final reflections on the extent to which the common law remains viable as a method of making social policy in an increasingly statutory age.

Questions of this sort have particular importance today, and not just because the expansion of legislation has made them more common. Ultimately, the proper division of policymaking between courts and legislatures is at stake. Partly as a result of public law theory, the relationship between courts and legislatures has become increasingly problematic.

At one time we had a clear idea of what legislatures did and how it differed from what courts did. Legislatures made ex ante rules to achieve public policies; courts administered ex post justice in disputes between private parties. Each body had the specialized abilities necessary to perform its functions properly. ${ }^{6}$ None of this is clear anymore. Since the time of the legal realists, the policymaking role of the courts has become undeniable, and that policymaking has taken an increasingly conscious ex ante perspective. ${ }^{7}$ Republicanism has helped illuminate the role of the courts in articulating public values. On the other hand, because of public choice, today we question the ability of the legislature to make good (or even coherent) public policy. So it is

6. H. Hart \& A. Sacks, The Legal Process 185-88 (tent. ed. 1958).

7. For a recent discussion of the policymaking role of the courts, see M. EISENBERG, THE NATURE OF THE COMMON LAw 1-3, 26-37 (1988). See generally Easterbrook, The Supreme Court, 1983 Term - Foreword: The Court and the Economic System, 98 HARV. L. REv. 4 (1984). 
increasingly hard to find the appropriate boundary between judicial and legislative policymaking.

Of course, a full understanding of the limits of judicial policymaking would require not only a more comprehensive consideration of the common law, but also of the judicial role in statutory and constitutional interpretation. ${ }^{8}$ With the help of the New Public Law, we seek here only to illuminate a part - though an important part - of the general problem of defining the appropriate boundaries of judicial policymaking in an increasingly statutory world.

\section{Defining the New Public LaW}

There are undoubtedly different ways to characterize the public law scholarship of the past decade or so. One of its most distinctive attributes (and the one on which we will focus) is the much more careful and explicit attention granted to political theory. Unlike the pluralist theories of the $1950 \mathrm{~s}$, currently influential theories reject the view that the public interest will automatically emerge from the conflicting efforts of interest groups. ${ }^{9}$ In particular, two new movements in the study of political institutions, republicanism and public choice theory, have had a major impact on legal scholarship in public law. In this Part, we briefly sketch the major outlines of these two movements and discuss the relationship that we see between them. We also consider whether the term "public law" helps in defining the scope of the New Public Law.

\section{A. What Is "New" About the New Public Law?}

One strand of the New Public Law derives from a communitarian strain in modern political thought that has become known as republicanism. "Republicanism" was hardly a household word even for public law scholars until the 1980 s. The term is unfortunately misleading: the political philosophy called "republicanism" has no particular connection with the Republican party. The general obscurity of the term is itself quite meaningful, for the neo-republicans claim to have rediscovered a forgotten yet fundamental strand of American political thought. For the uninitiated, a brief, ruthlessly oversimplified intro-

8. For discussions by one prominent theorist of how republicanism and public choice might influence constitutional law, administrative law, and statutory interpretation, see C. SUNSTEIN, AfTER THE RIGHTS Revolution (1990), reviewed in Farber, Playing the Baseline: Civil Rights, Environmental Law, and Statutory Interpretation, ColUM. L. REV. (forthcoming). Some of our thoughts about constitutional law in this regard are reflected in D. FARBER \& P. FRICKEY, LAW AND PUBlic Choice: A CRITICAL InTroduction ch. 4 (1991).

9. See infra text accompanying notes 16-22 (discussing republicanism), text accompanying notes 23-32 (discussing public choice theory). 
duction will suffice for our purposes. ${ }^{10}$

The dominant strand of American political philosophy has been liberalism - another misleading term, since philosophical liberalism is at least as much embraced by political conservatives as liberals. Philosophical liberalism begins with the individual rather than the community ${ }^{11}$ and posits that individuals have basic human rights that exist independent of any particular political system. Political conservatives may view these rights as involving property; political liberals may stress rights of individual self-expression or equality; but both agree that these rights are constraints on government rather than creations of government. ${ }^{12}$

Liberalism also assumes that individuals have interests that they seek to advance, both in private life and in politics. ${ }^{13}$ The government's role is defined in terms of these individual interests while respecting individual rights. ${ }^{14}$ One important function of government, therefore, is to provide fair procedures for determining who prevails when individuals or groups conflict. ${ }^{15}$

Philosophical liberalism is the dominant strain in current American thought. In the eighteenth century, however, another political tradition - republicanism - was also highly influential. ${ }^{16}$ During the Revolutionary era, many prominent Americans were strongly influenced by the teachings of the seventeenth-century Opposition party in England. The Opposition thinkers had decried the destruction of the old order, the rise of corruption, and the loss of civic virtue. The fate of the nation, they believed, rested on the willingness of individuals to sacrifice private interests to the common good. ${ }^{17}$

Modern reconstructions of republicanism are based on the allure of

10. Readers who are not familiar with the republicanism literature would do well to start with the symposium on the subject in the July 1988 issue of the Yale Law Journal. See Sympo. sium: The Republican Civic Tradition, 97 YALE L.J. 1493 (1988). The articles by Michelman and Sunstein exemplify the efforts to modernize republicanism, while the commentators offer a number of probing challenges to that effort. Another excellent critique of republicanism can be found in Fitts, The Vices of Virtue: A Political Party Perspective on Civic Virtue Reforms of the Legislative Process, 136 U. PA. L. REV. 1567 (1988).

11. See, e.g., Michelman, Conceptions of Democracy in American Constitutional Argument: Voting Rights, 41 FLA. L. Rev. 443, 445-52 (1989).

12. Compare J. Rawls, A Theory of JUstice 3 (1971) with R. Nozick, ANARchY, STATE, AND UTOPIA 88-90 (1974).

13. J. RAWLS, supra note 12 , at 4.

14. Id. at 5-6.

15. See, e.g., Michelman, supra note 11 , at 449.

16. For a summary of the historical literature, see D. FARBER \& S. SHERrY, A HistorY of THE AMERICAN CONSTITUTION ch. 1 (1990).

17. Legislative abuses between 1776 and 1789 disillusioned many prominent Americans about popular virtue as a sufficient basis for democracy, and they turned to alternate theories of government. The republican influence remained, however, particularly among the anti-Federal- 
civic virtue. ${ }^{18}$ Political life is not, as liberalism posits, merely an effort to use the machinery of government to further the ends of private life. Rather, politics is a distinct and in some respects superior sphere in which citizens rise above their merely private concerns to join in a public dialogue to define the common good. ${ }^{19}$ Indeed, one of the most important tasks of government is to make the citizenry more virtuous by modifying existing individual preferences to further the common good. ${ }^{20}$

According to republicans, courts can play an important role in this process. As forums for public deliberation, courts can identify and promote the acceptance of public values. ${ }^{21}$ Courts can also ensure that the decisions of other agencies of the government reflect republican deliberation rather than an equilibrium of private interests. ${ }^{22}$

On the surface, at least, public choice theory ${ }^{23}$ stands in stark contrast to republican theory. Public choice usually claims to be positive while republicanism is explicitly normative, and the implications of public choice seem as dismal as those of republicanism seem optimistic. Again, because of its recent prominence, we will present only a brief, simplified overview of public choice for the uninitiated. ${ }^{24}$

As we see it, public choice theory is a hybrid: it applies the economist's methods to the political scientist's subject. Public choice is largely concerned with abstract, axiomatic modeling of political processes. These models often view the legislative process as a microeconomic system in which "actual political choices are determined by the efforts of individuals and groups to further their own interests," 25 efforts that have been labeled "rent seeking." 26 Thus,

ists who opposed the new Constitution, but possibly also to some degree among Federalists such as James Madison. See id. at 15-19.

18. The best statements of the modern republican position can be found in Sunstein, Interest Groups in American Public Law, 38 STAN. L. REV. 29 (1985), and Michelman, The Supreme Court, 1985 Term - Foreword: Traces of Self-Government, 100 HARV. L. REV. 4 (1986).

19. Sunstein, supra note 18 , at 31 .

20. See, e.g., Sherry, Civic Virtue and the Feminine Voice in Constitutional Adjudication, 72 VA. L. REV. 543 (1986).

21. Sunstein, supra note 18 , at 52 .

22. See, e.g., id. at 63-64.

23. Because this is such a new field, even its title is not yet settled, with some scholars preferring terms such as "rational choice" or "the new institutionalism." The standard term in the legal literature, however, is public choice. See D. FARBER \& P. FRICKEY, supra note 8, Introduction.

24. For a more detailed treatment, see D. FARBER \& P. FRICKEY, supra note 8.

25. Becker, A Theory of Competition Among Pressure Groups for Political Influence, 98 Q.J. ECON. 371, 371 (1983).

26. "Rent-seeking refers to the attempt to obtain economic rents (i.e., payments for the use of an economic asset in excess of the market price) through government intervention in the mar- 
"[t]he basic assumption . . . is that taxes, subsidies, regulations, and other political instruments are used to raise the welfare of more influential pressure groups."27

Further, collective action problems make it difficult to organize large groups of individuals to seek broadly dispersed public goods. ${ }^{28}$ Public choice suggests that political activity will instead be dominated by small groups of individuals seeking to benefit themselves. ${ }^{29}$ The most easily organized groups presumably consist of a few individuals or firms seeking government benefits for themselves, benefits which will be financed by the general public. Accordingly, under this view "rent-seeking" special interest groups dominate politics.

This vision of politics is disturbing precisely because it suggests that there is an underlying, coherent pattern to political outcomes, but one that most people find normatively unattractive. The implications of another branch of public choice theory are, if anything, even more dismal. Some public choice theorists have suggested that, far from systematic rent-seeking, political processes necessarily lead to entirely arbitrary or incoherent outcomes. ${ }^{30}$

ket." Macey, Promoting Public-Regarding Legislation Through Statutory Interpretation: An Interest Group Model, 86 CoLUM. L. REv. 223, 224 n.6 (1986).

27. Becker, supra note 25, at 373-74. For example, the economic theory of legislation recounted by William Landes and Richard Posner is firmly grounded in that tradition:

In the economists' version of the interest-group theory of government, legislation is supplied to groups or coalitions that outbid rival seekers of favorable legislation. The price that the winning group bids is determined both by the value of legislative protection to the group's members and the group's ability to overcome the free-rider problems that plague coalitions. Payment takes the form of campaign contributions, votes, implicit promises of future favors, and sometimes outright bribes. In short, legislation is "sold" by the legislature and

"bought" by the beneficiaries of the legislation.

Landes \& Posner, The Independent Judiciary in an Interest Group Perspective, 18 J.L. \& EcoN. 875, 877 (1975) (footnote omitted).

28. The economic analysis of interest group politics can be traced to Mancur Olson's theory of collective action. See M. Olson, The Logic of Collective ACTION: Public Goods AND THE THEORY OF GROUPS (1965). Political action often confers benefits on large groups. For example, everyone presumably benefits from improved national security. An individual's actions in support of national security, however, normally can have only an infinitesimally small effect. Hence, a rational individual will try to "free ride" on the efforts of others, contributing nothing to the national defense while benefiting from other people's actions. W. EskridGE \& P. FRICKEY, supra note 1, at 48-49.

29. See, e.g., Macey, supra note 26, at 231-32. As Becker points out, most groups involved in politics suffer from free rider problems. What is important is the relative rather than absolute degree of free riding, since this determines the relative power of the group. See Becker, supra note 25 , at 380 .

30. Concern about the possible incoherence and meaninglessness of legislative outcomes stems from Arrow's Theorem, which demonstrates the impossibility of designing a completely rational method of making group decisions. D. FARBER \& P. FRICKEY, supra note 8, ch. 2 (discussing Arrow's Theorem). A simple example illustrates the heart of the difficulty. Suppose that three legislators must vote on where to locate a new federal facility, and that their preferences are as follows: 
Jerry Mashaw has aptly summarized the potentially dismal implications of the research inspired by Arrow's Theorem:

The most basic finding of the Arrovian branch of public choice theory might be characterized as indicating that collective action must be either objectionable or uninterpretable. A stable relationship between the preferences of individuals and the outcomes of collective choice processes can be obtained only by restrictions on decision processes that most people would find objectionable. At its most extreme, Arrovian public choice predicts that literally anything can happen when votes are taken. At its most cynical, it reveals that, through agenda manipulation and strategic voting, majoritarian processes can be transformed into the equivalent of a dictatorship. In a more agnostic mode, it merely suggests that the outcomes of collective decisions are probably meaningless be-

Legislator 1 prefers Texas to Illinois, and Illinois to Florida.

Legislator 2 prefers Illinois to Florida, and Florida to Texas.

Legislator 3 prefers Florida to Texas, and Texas to Illinois.

Now suppose that the legislators will first decide between Texas and Illinois, with the winner to be paired against Florida. Texas will win the first round, receiving support from legislators 1 and 3 , but Florida will end up with the facility because legislators 2 and 3 prefer it to Texas on the second round of voting. Unfortunately, it is apparent that Florida does not represent the "majority will," because two of the three legislators prefer Illinois to Florida. In fact, unless procedural rules restrict how many motions can be made, the voting could continue forever. On a majority vote, Illinois loses to Texas, Texas loses to Florida - but Florida loses to Illinois, so we are right back where we started. The legislators are trapped in a revolving door with no exit.

Arrow was interested in the problem of measuring social welfare. Given the varying preferences of individuals, when does a change make society as a whole better off? Rather than identifying a method of answering this question, he ultimately proved that an answer is impossible. More precisely, he showed that no method of combining preferences can satisfy such basic requirements as the following:

(a) Minimum rationality. If society prefers outcome $A$ to outcome $B$ and outcome $B$ to outcome $C$, then society prefers $A$ over $C$.

(b) The Pareto standard. If one individual prefers $A$ over $B$ and no one else cares, then society prefers $A$ over $B$.

(c) Nondictatorship. Society's preferences do not simply reflect the desires of one given individual.

(d) Universal applicability. The method has to work for any possible combination of individual preferences, not just for particular situations.

(e) Irrelevant alternatives. If $C$ is not on the agenda, the choice between $A$ and $B$ should not depend on how they are ranked relative to $C$.

These are obviously quite modest aspirations, either for a method of measuring social welfare or for a system of social decisionmaking. And yet, as Arrow demonstrated, even these modest aspirations cannot be satisfied.

One might hope that, while cycling is a theoretical possibility, it would not occur very often. Later work, however, suggests that under plausible circumstances there will be a complete cycle. That is, given any two outcomes $A$ and $Z$, where a majority prefers $A$ to $Z$, there will be a series of outcomes $B, C, \ldots Y$, such that $A$ is beaten by $B, B$ beaten by $C$, and so forth down to $Y$, which in turn is beaten by $Z$. $A$ would beat $Z$ in a direct vote, but a series of motions could successfully be made replacing $A$ with other alternatives, which would ultimately result in adoption of $Z$. This possibility gives enormous power to the agenda setter. The person in charge of the agenda could guarantee the adoption of $A$ by pitting $A$ and $Z$ against each other in a direct vote. On the other hand, the agenda setter could obtain the passage of $Z$ by scheduling intermediate votes involving $B$ through $Y$. The result would then be that $A$ would lose to $B, B$ to $C$, and so on, until finally $Y$ is replaced by $Z$. What looks like majority rule is actually within the complete control of the person who controls the agenda, who can exploit the possibility of a cycle to dictate the outcome. D. FARBER \& P. FrICKEY, supra note 8, ch. 2; see P. ORDESHOoK, GAME THEORY AND POLITICAL THEORY: AN INTRODUCTION 71-82 (1986). 
cause it is impossible to be certain that they are not simply an artifact of the decision process that has been used. ${ }^{31}$

As Mashaw implies, much of the public choice literature makes for fairly grim reading, offering the choice between viewing legislatures as corrupt or mindless. This grimness seems to be diminishing in recent public choice scholarship. Recent studies have shown that legislators are not merely pawns of special interest groups and that a variety of stabilizing devices may allow legislatures to escape incoherence. ${ }^{32}$ Nevertheless, it is fair to say that public choice still tends to emphasize the frailties of democratic government. ${ }^{33}$

As we have characterized the New Public Law, its main feature is the self-conscious use of political theory. Yet the two branches of political theory that have been most influential are clearly in tension. Under public choice theory government functions as a mechanism for combining private preferences into a social decision. The preferences themselves remain untouched. In contrast, in republican thought private preferences are secondary; preferences are if anything the products of government action rather than its inputs. ${ }^{34}$ Rather than mechanically processing preferences, government involves an intellectual search for the morally correct answer. ${ }^{35}$

31. Mashaw, The Economics of Politics and the Understanding of Public Law, 65 CHI.-KENT L. REV. 123, 126-27 (1989) (footnotes omitted).

32. See D. FARBER \& P. FRICKEY, supra note 8, chs. 1-2.

33. In an ambitious article, Richard Pildes and Elizabeth Anderson argue that Arrow's Theorem does not pose any threat to democratic legitimacy. Pildes \& Anderson, Slinging Arrows at Democracy: Social-Choice Theory, Value Pluralism, and Democratic Politics, 90 CoLum. L. REV. 2121 (1991). Although space does not permit a full discussion of their thesis, we have some brief comments. Much of the article (Part II, "Reconceiving Rationality"), purports to be an attack on social choice theory, but is in reality an attack on the theory of rational choice adopted by most economists. Since public choice is an application of economic thought to political problems, it is not unexpected that it suffers from whatever flaws may generally be found in the discipline of economics. (The authors come close to making this explicit later in the article, at $p$. 2177 n.139, but Part II makes the point fairly clear by applying many of its arguments to individual as well as to collective choice.) We leave it to the economists to defend the viability of their discipline. In our view, the Pildes and Anderson argument on this point has some force in those situations where basic values are sharply in conflict, but they may well overestimate the extent to which this is true of ordinary governmental decisions.

Only in Part III of the article do the authors turn specifically to the problem of voting paradoxes. There, they echo the argument made earlier by one of us that democratic procedures cannot be assessed purely on the basis of voting outcomes, but must be assessed in large part based on the basis of other vital norms and institutions. See Farber, Democracy and Disgust: Reflections on Public Choice, 65 CHI.-KENT L. REV. 161, 171-76 (1989). See also infra note 36. They also argue that "path dependence" should not be considered a serious problem (pp. 2196. 97), an argument that we regard as important and persuasive. As we understand it, their conception of democracy does not stress majority rule but rather equal participation. Because voting is peripheral to their concept of democracy, it is unsurprising that they find flaws in majority voting procedures to be of little concern. But we suspect that many of our readers think that majority rule is an important feature of democracy, and that its potential flaws are troublesome.

34. See infra notes 50-51 and accompanying text.

35. As Frank Michelman has written of the republican elements in Rousseau's thought: 
It would be hard to imagine a vision of representative government that differs more than republicanism from the rent-seeking models we discussed earlier or from the chaos and cycling of Arrow's Theorem. ${ }^{36}$ This contrast forms the basis for much of the appeal of republicanism. Where public choice theorists are prone to see haphazard cycling or rent-seeking by special interest groups, republicans find the possibility of genuine political dialogue in search of the public good. ${ }^{37}$

This is not the place for a full rendition of our views on republicanism and public choice, but a few brief reflections are relevant to our later discussion. We find some of the lessons of republicanism attractive: ideas as well as pocketbooks matter in politics, civic-mindedness is more than a myth, and government can be a moral teacher as well as a reflection of public opinion. While it is possible to overemphasize these elements of political life, we think it equally wrong to dismiss them. Nevertheless, where public choice theory risks cynicism, republicanism can verge on a dangerous romanticism about politics. Although contemporary republicans concede that the political process is subject to rent-seeking, they may overestimate the extent to which public deliberation elevates political outcomes over prior

It follows from the Rousseauean view that majoritarian politics cannot be only the individualistically self-serving activity "realistically" portrayed by economics-minded political scientists and theorists. Politics must also be a joint and mutual search for good or right answers to the question of directions for our evolving selves. In other words, to hold to Rousseau's view we must be able to imagine ourselves voting for the Endangered Species Act . . . although we would not as individuals be willing (or bet that our constituents would be willing) to pay any measurable sums of money for the enactment of that principle; and although no one has offered us anything in exchange for our vote, explicitly or implicitly; and although we know well that we may some day find our own private projects inconvenienced or thwarted by the statute and the principle to which we are now committing ourselves.

Michelman, Politics and Values or What's Really Wrong With Rationality Review?, 13 CREIGHTON L. REv. 487, 509-10 (1979) (footnote omitted).

36. In Law and Public Choice we discuss a possible Madisonian reconciliation between these visions. D. FARBER \& P. FRICKEY, supra note 8, at ch. 2. Briefly, we suggest that public choice supports republicanism in its rejection of the pluralist view that the political process is a purely passive reflection of preexisting preferences. As Arrow's Theorem demonstrates, preexisting preferences cannot be coherently combined to generate social choices. Rather, preferences have to be processed through the legislative machinery, applying norms such as fairness and using committees and other stability-enhancing devices. Legislative choice is also expedited if there is sufficient cultural consensus to generate unipeaked preferences along single dimensions of dispute. By undermining pluralism, social choice provides support for at least a weak form of republicanism in which government is seen as not merely passive but instead as actively processing existing preferences.

37. In particular, republicans can escape from the dismal implications of Arrow's Theorem by rejecting the entire perspective on politics behind the theorem. Arrow's Theorem sees politics as a machine, with preferences as the input and decisions as the output. For republicans, however, preferences are shaped by politics, while dialogue and reason are the energizing forces behind political decisions. From a republican perspective, the only surprise about Arrow's Theorem is that it is possible to prove mathematically what republicans regard as an obvious truth: that government cannot simply be the handmaiden of private preferences. 
preferences. ${ }^{38}$

Given that public choice emphasizes the possible pathologies of democratic government while republicanism considers government's possible accomplishments, it is little wonder that the two have appealed to different groups of scholars. Conservatives who are suspicious of government have found in public choice a congenial catalogue of political misdemeanors, while progressive communitarians have been drawn to republicanism. For this reason, the New Public Law has developed along somewhat different left- and right-wing lines. Nevertheless, the two may be used in tandem, with republicanism serving to illuminate the normative possibilities of democratic government and public choice highlighting its potential pitfalls. ${ }^{39}$

One of our purposes here is to suggest that these two very different theories can effectively be combined in legal analysis, although doing so does risk some cognitive dissonance. It would be nice, of course, if the political scientists would present us with some grand synthesis combining public choice and republicanism. But the New Public Law can offer considerable insight even without such a synthesis. ${ }^{40}$

\section{B. What Is "Public" About the New Public Law?}

We suggest that the New Public Law can illuminate some interesting common law problems. ${ }^{41}$ For many people, however, "common

38. Where political positions are reinforced by self-interest, discussion will not likely cause major changes. Regardless of argument, individuals are likely to cling to their own political views, not because those views are merely camouflaged self-interest but because it is so tempting to embrace beliefs that are also in one's self-interest. Moreover, in important political disputes, neither side is likely to have a knock-down argument. Often, the facts will be in dispute or clashing values will resist philosophical resolution. This is not to say that political debate is fruitless, but only that we should not view it as a panacea.

39. For an early example of this use of the theories in tandem, see Eskridge, Dynamic Statutory Interpretation, 135 U. PA. L. REV. 1479 (1987).

40. The use of such diverse tools to analyze legal issues is consistent with our overall jurisprudential bent toward antiformalism - "practical reason" or "pragmatism" - as opposed to foundationalist legal theory. See generally Farber \& Frickey, Practical Reason and the First Amendment, 34 UCLA L. REV. 1615 (1987).

Before we leave our parsing of the term "New Public Law," we note that in an important sense there is nothing "new" about analyzing public law from the viewpoints of public choice and republicanism. Public choice shares much with Blackstonian common law formalism, under which the legislature was seen as an unpredictable and unprincipled interloper into the preferred state of affairs, private ordering. See generally W. ESKRIDGE \& P. FRICKEY, supra note 1, ch. 3, $\S 1$. Republicanism, too, links up well with an earlier epoch of public law, the New Deal, in which judicial deference to legislative value judgments about the common good became the order of the day. See Sunstein, Constitutionalism After the New Deal, 101 HARv. L. REV. 421 (1987). In a sense, when they are transported into the public law domain, public choice provides an axiomatic pedigree to Blackstonian formalism, and republicanism lends a historical, traditional aura to New Deal reformism.

41. For an important earlier effort to apply the New Public Law to some "private law" problems, see Komesar, Injuries and Institutions: Tort Reform, Tort Theory, and Beyond, 65 N.Y.U. L. REV. 23 (1990). 
law" and "public law" are antonyms. How, then, can the New Public Law have anything to say about the common law of torts? To address these concerns, we must first examine the distinction between public and private law. ${ }^{42}$ To the extent that this distinction has any remaining vitality, it has little relevance to defining the scope of the New Public Law.

We begin by considering the conventional classification of various fields of law. .33 Torts and contracts are usually considered examples of private law; constitutional and administrative law exemplify public law. But it is hard to know what features of these examples are definitive. Private law is often common law rather than statutory, but the Uniform Commercial Code has not converted Sales into public law, at least in the minds of law professors. Conversely, the use of common law methodologies does not make constitutional law, section 1983, or Title VII into private law fields. ${ }^{44}$ Procedurally, "public law" litigation often involves more parties, more flexible relief, and more judicial initiative than classic private law disputes, but it is not hard to find exceptions on both sides. ${ }^{45}$ Often, the government is a party to public law litigation, but many important regulatory schemes rely in whole or in part on private litigation as an enforcement tool. ${ }^{46}$ None of these differences seems decisive.

In an earlier age, the distinction between public and private law had deep jurisprudential roots. In nineteenth-century legal thought, the public/private distinction was founded on the idea of an autono-

42. Something more is at stake here than semantics. Speaking more generally of the public/ private distinction, Jack Balkin has recently observed that it has a kind of irrepressibility, so that even those who reject its meaningfulness are ultimately driven to recreate it. Balkin, Nested Oppositions (Book Review), 99 YALE L.J. 1669, 1687-88 (1990).

43. When we first thought about our topic as a possible contribution to this symposium, we were unsure whether it fell under the rubric of the New Public Law. We solicited opinions from a variety of law professors about the meaning of "public law," and received almost an equally great variety of answers. The most striking answer was given (tongue in cheek) by a member of the Yale faculty, who opined that "public law is what too many people on this faculty want to teach." Another noteworthy definition is found in Justinian's Institutes: public law is that "concerned with sacred rites, with priests, and with public officers." Pound, Public Law and Private Law, 24 CORNELL L.Q. 469, 470 (1939). A cynic might note that both definitions fit the prototypical modern public law subject - constitutional law - pretty well, but even if that is true, neither is very useful for present purposes.

44. Nor is the distinction between adjudication and rulemaking decisive; some rules (like the Miranda wamings) are created by courts, while some adjudication is performed by agencies such as the National Labor Relations Board, yet both are public law.

45. Chayes's classic article suggested that these procedural features were unique to public law. Chayes, The Role of the Judge in Public Law Litigation, 89 HARv. L. REv. 1281, 1284 (1976). Similar features do exist in private law. See Eisenberg \& Yeazell, The Ordinary and Extraordinary in Institutional Litigation, 93 HARV. L. REV. 465, 466 (1980).

46. See, e.g., Cannon v. University of Chicago, 441 U.S. 677 (1979). 
mous private order. ${ }^{47}$ Private law was designed to protect these prepolitical rights. ${ }^{48}$ Property law arbitrated disputes about ownership; tort law protected owners from unconsented intrusions; and contract law allowed owners to exchange property. ${ }^{49}$ Private law, then, was that part of the legal system protecting the private ordering; public law consisted of government compulsions restricting private freedom.

This vision of a prelegal private ordering was a major target of the legal realists, and today has been attacked by critical legal scholars and neo-republicans. ${ }^{50}$ They have argued cogently that the common law itself is based on choices of public policy. Today, in considering issues of contract, tort, or property law, it is almost second-nature to refer to considerations of public policy. Despite the realist critique, it may be possible to salvage something of the distinction between rules that uphold private ordering versus those that override private ordering. ${ }^{51}$ Elaborating this distinction would be no easy matter, however, since most fields of law contain some rules of both types. ${ }^{52}$ Moreover, the distinction between facilitative and supervening legal rules may itself be problematic. Private law does not endorse all private activity. It attempts to distinguish between "coercive" and "voluntary" transactions, to identify those actions that do further private preferences. These distinctions, however, are themselves often controversial. ${ }^{53}$

47. See Kennedy, Toward An Historical Understanding of Legal Consciousness: The Case of Classical Legal Thought in America, 1850-1940, 3 REs. L. \& Soc. 3, 6-9 (1980). (1988).

48. Sunstein, Standing and the Privatization of Public Law, 88 CoLuM. L. REv. 1432, 1435

49. Grey, supra note 1 , at 48.

50. See Sunstein, supra note 48, at 1435-38; Singer, Legal Realism Now (Book Review), 76 CALIF. L. Rev. 465, 478-82 (1988).

51. The realist/republican critique has a valid point but may be overstated to the extent that it portrays private preferences and transactions as wholly the creations of the legal system. Private preferences are surely subject to government influence, but these preferences can also be quite resilient. For example, almost 50 years of intensive governmental efforts have failed to persuade the people of Eastern Europe of the virtues of communism. It is also perhaps unrealistic to think that markets are purely creatures of government. Some markets, such as those for illegal drugs, can thrive without any supporting legal rules, and indeed in direct contravention of legal rules.

52. For example, property law has many facilitative rules, but the Rule Against Perpetuities overrides private decisions. On the other hand, discrimination law is mostly considered public law, but at least some of its rules, such as sexual harassment standards, can also be seen as aimed at preventing coercive invasions of private rights.

53. For example, if labor law is conceived as a means of overcoming an imbalance of bargaining power, so as to allow workers to enter into truly voluntary bargains with employers, then the National Labor Relations Act is part of private contract law. On the other hand, the NLRA can also be considered a rent-seeking interference with the competitive labor market. Thus, a reference to "voluntary" exchanges requires a controversial and somewhat political judgment about the nature of labor markets.

Similarly, in speaking of implementation of, rather than interference with, private preferences, we ignore the difficult problem of determining when behavior accurately reflects private preferences, rather than the effects of market failures, incomplete information, cognitive limita- 
If the private law/public law distinction retains any vitality after the realist critique, the line between the two is at best elusive. Fortunately, we need not resolve the issue here. So far as we can see, whether republicanism and public choice are useful analytic tools does not depend on whether a legal rule is ultimately facilitative or supervening. ${ }^{54}$

We suggested earlier that the distinctive attribute of the New Public Law is its explicit reliance on postpluralist political theory. Whether the New Public Law is useful in a particular instance depends, consequently, on whether such political theory helps to solve the problem at hand. Thus, what determines the relevance of the New Public Law is not the substance of the legal issue, but whether an understanding of political institutions seems necessary. Not surprisingly, this most often occurs when the legal issue is formulated from the outset as relating to the proper role of government, or when the interpretation of a governmental act is at stake. But even in other kinds of cases, the perspective of political theory may be important.

In the "market" for legal ordering, the legislature is always a "potential entrant." When a court is asked to make rules to govern a private transaction, it is often relevant that the legislature or its administrative agent are possible alternate decisionmakers. ${ }^{55}$ Indeed, today, some legislative act such as the Uniform Commercial Code is often implicated in even the most "private law" case. Once either legislation or the potential of legislation enters the case, the same political theories that have helped shape the New Public Law may become important sources of insights regardless of whether the issue is considered public or private law.

In short, we believe that the "New Public Law" is a misnomer. Although it has its origins in fields that were traditionally considered "public law," the applicability of this body of theory is only contingently related to whatever remains of the public law/private law distinction. The New Public Law is potentially useful in analyzing a

tions, or various personality disorders such as addiction that prevent individuals from implementing their true preferences. See generally Sunstein, Legal Interference with Private Preferences, 53 U. CHI. L. REv. 1129, 1173 (1986) (noting distortions in a system based on private preferences that require collective intervention). Again, drawing these lines will often be highly controversial. How we draw these lines determines, for example, to what extent consumer protection statutes are considered essentially private law.

54. Nor, for that matter, does it have any necessary connection with the other possible indicia of public versus private law, such as whether the government is a party to the case, whether the case involves prospective relief in a multipolar proceeding, or whether the case is common law or statutory.

55. For example, the possibility of legislative action is important to fashioning stare decisis rules even in common law cases. See, e.g., Moragne v. States Marine Lines, 398 U.S. 375 (1970). 
wide variety of legal problems outside the domain of public law, as classically understood. It is to a couple of brief illustrations of this point that we now turn.

\section{The Viability of the Common LaW IN THE AGE of STATUTES}

In an age in which so much public policy is made by legislatures, the role of the common law can no longer be taken for granted. When a statute is directly applicable, it of course displaces any conflicting common law rules (constitutional limits aside). ${ }^{56}$ Our interest, however, is in situations where the existence of a statute may affect judicial policymaking outside of the statute's domain. ${ }^{57}$

Traditionally, judges viewed the common law as a principled, hermetically sealed system immune from all but clear statutory intrusions. ${ }^{58}$ Statutes were "in the law," - they were formal requirements of positive law - but not "of the law" because they were the work of an unprincipled and unpredictable agency, the legislature. With the demise of most aspects of common law formalism and the rise of the age of statutes, courts began considering statutes as potential sources of worthwhile principles, rather than simply reflections of brute political power. This development conceptualized the legislature as an appropriate potential player in any common law policymaking dispute, not simply another government agency from which disappointed litigants could seek relief. In essence, common law courts began viewing themselves as operating in the shadow of the legislature, especially where the legislature had enacted statutes having a penumbral relationship with the common law problem at hand.

Conceptualizing the legislature as a source of public policy has re-

56. See, e.g., Farber, Statutory Interpretation and Legislative Supremacy, 78 GEO. L.J. 281 (1989).

57. The two examples we will discuss are drawn from the federal common law. We have chosen them because we believe they illustrate our point effectively, because they are probably fairly well known to many public law scholars, and for the eminently practical reason that we know about them from our prior scholarship and teaching. By treating the federal common law as essentially similar for illustrative purposes with state common law, we are necessarily disagreeing with any narrow, formalist conception of the federal sphere. Cf. Redish, Federal Common Law, Political Legitimacy, and the Interpretive Process: An "Institutionalist" Perspective, 83 Nw. U. L. REV. 761 (1989). Although the domain of federal common law is more restricted (in part for the reasons that Redish discusses), we see no difference between the way federal common law functions within its domain and the way state common law functions. (Although state judges do not have life tenure, we doubt that the electoral process can or should function as a referendum on common law rules, or that state judicial decisions in particular cases are shaped by electoral concerns.) Of course, even if we are wrong about the scope of the federal common law, what we say has relevance to the common law in general.

58. For an overview supporting this and the other points made in this paragraph, see $W$. ESKRIDGE \& P. FRICKEY, supra note 1, at 241-47. 
publican connotations, and public choice is implicated when viewing the legislature as a potential entrant into any dispute about public policy. In this section, we illustrate the role that republicanism and public choice might play in analyzing common law problems in the age of statutes. We examine two juxtapositions of statutes and the common law from republican and public choice perspectives. Both situations involve torts, traditionally a paradigm "private law" field. In both, however, applying the New Public Law provides insights into the appropriate judicial role.

The common law and statutes may interact in two distinct ways. In tort law, for example, conduct is often subject to a case-by-case judgment about reasonableness. In these cases, judicial policymaking takes place at the microlevel, when the common law rule of reasonableness or balancing is applied. If the legislature later adopts a statute regulating conduct subject to this kind of common law rule, the question becomes whether such microlevel judicial policy decisions have become inappropriate. Here, a legislative scheme may result in a curtailment or even the abandonment of the common law approach. We illustrate this question by examining whether the Supreme Court should have abandoned the established federal common law of interstate nuisance in light of the adoption of the Clean Water Act.

In our second example, we consider an instance in which the common law, contrary to its usual approach of case-by-case judgments about reasonableness, has a flat rule barring recovery for injuries arising from certain conduct. Suppose that the legislature later adopts statutes inconsistent with the policies underlying the common law rule but not directly abrogating it. Should the courts administer the coup de grace to what remains of the common law rule, in deference to the legislature's policy judgment? Or, on the contrary, should the courts consider what remains of the common law frozen, in deference to the legislature's possible assumption of policymaking responsibility over the subject matter?

While disputes of these two kinds are frequently before the courts, they have received relatively little systematic attention from scholars. Our purpose in this Part is to explore these issues from the perspective of the New Public Law. Not surprisingly, considering the normative and empirical issues that lurk in these cases, republicanism and public choice help in analyzing these common law problems.

\section{A. Micro-Policymaking Within Existing Common Law Rules}

The micro-policymaking issue is nicely posed by a series of cases 
dealing with the federal common law of interstate nuisance. ${ }^{59}$ The pivotal decision is City of Milwaukee v. Illinois [Milwaukee II], ${ }^{60}$ but some background is necessary to put the opinion into perspective.

The federal common law of interstate nuisance traces back to Georgia v. Tennessee Copper Co., ${ }^{61}$ an original action against a Tennessee company whose pollution was causing widespread damage in Georgia. The Supreme Court entertained the action because the dispute involved the state of Georgia's quasi-sovereign interest in its air quality:

When the States by their union made the forcible abatement of outside nuisances impossible to each, they did not thereby agree to submit to whatever might be done. They did not renounce the possibility of making reasonable demands on the ground of their still remaining quasi-sovereign interests; and the alternative to force is a suit in this court. ${ }^{62}$

In a similar case, seeking to take advantage of the Supreme Court's original jurisdiction, Illinois filed a nuisance action against the City of Milwaukee, alleging that Milwaukee was discharging 200 million gallons of untreated sewage into Lake Michigan daily. In Illinois v. City of Milwaukee [Milwaukee I], ${ }^{63}$ a unanimous Court dismissed the original action on the ground that Illinois had an alternate remedy in federal district court. The Court held that the federal common law of nuisance was a proper basis for federal question jurisdiction. In recognizing a federal cause of action, the Court relied on three factors: (1) the quasi-sovereign nature of the state's interest; ${ }^{64}(2)$ the need for a uniform rule of decision governing nuisance in interstate waters; ${ }^{65}$ and (3) strong congressional concern over water pollution. ${ }^{66}$

Soon after the decision in Milwaukee $I$, Congress substantially amended the federal water pollution statute, creating what is now called the Clean Water Act. ${ }^{67}$ In Milwaukee II, almost a decade later,

59. This problem is not unique to the federal courts. For example, in Boomer v. Atlantic Cement Co., 26 N.Y.2d 219, 222-23, 226, 257 N.E.2d 870, 871, 309 N.Y.S.2d 312, 314-15 (1970), the court held that in fashioning an appropriate remedy in a nuisance case, only the interests of the private parties before the court should be considered, rather than the broad public interest in controlling air pollution. Since the public interest is a traditional factor in shaping equitable decrees, see, e.g., D. DoBBS, HANDBOOK ON THE LAW OF REMEDIEs 65 (1973); Shane, Rights, Remedies and Restraint, 64 CHI.-KENT L. REV. 531, 565 (1988), this is a retreat from the traditional policymaking role of the courts.

60. 451 U.S. 304 (1981).

61. 206 U.S. 230 (1907).

62. 206 U.S. at 237.

63. 406 U.S. 91 (1972).

64. 406 U.S. at 104-05, 107.

65. 406 U.S. at 105 n.6, 107 n.9.

66. 406 U.S. at 101-02.

67. Federal Water Pollution Control Act Amendments of 1972, Pub. L. No. 92-500, 86 Stat. 816 (codified in scattered sections of 12 U.S.C., 15 U.S.C., 31 U.S.C., and 33 U.S.C.). For a 
the Supreme Court held that the 1972 Amendments preempted the federal common law of nuisance. The Court began with the propositions that the federal courts, unlike state courts, are not courts of general jurisdiction and that the creation of a federal rule of decision is generally the job of Congress; federal common law is thus the exception rather than the rule. ${ }^{68}$ (As we explain later, we consider this emphasis on the unique nature of federal common law to be a red herring. ${ }^{69}$ ) The Court reasoned that the federal regulatory scheme displaced the "often vague and indeterminate nuisance concepts and maxims of equity jurisdiction" embodied in the federal common law of nuisance. ${ }^{70}$

Two later cases complete the story of interstate nuisance law. In Middlesex County Sewerage Authority v. National Sea Clammers Association, ${ }^{71}$ the Court held that the federal common law of nuisance was preempted even though, as the dissent pointed out, the defendants violated the federal pollution statute. ${ }^{72}$ But in International Paper Co. $v$. Ouellette, $^{73}$ the Court allowed a diversity action against an interstate polluter, ruling that the Clean Water Act preempts the federal common law and the nuisance law of the receiving state, but does not preempt the nuisance law of the discharging state. ${ }^{74}$ The latter conclusion was well-nigh unavoidable because the Clean Water Act contains a powerful savings clause. ${ }^{75}$ The upshot is that there is no

discussion of the 1972 amendments, see R. FindLEY \& D. FARBER, ENVIRONMENTAL LAW: CASES AND MATERIAIS 264-65 (2d ed. 1985).

68. 451 U.S. at 312-13.

69. See infra text accompanying notes 81-83. Moreover, we doubt if the Milwaukee II Court's reservations about the legitimate scope of federal common law remain good law after Boyle v. United Technologies Corp., 108 S. Ct. 2510 (1988). For further discussion of Boyle, see note 113 infra.

70. 451 U.S. at $317,319-26$. "It would be quite inconsistent" with the federal statutory scheme, the Court said, "if federal courts were in effect to 'write their own ticket' under the guise of federal common law after permits have already been issued and permittees have been planning and operating in reliance on them." 451 U.S. at 326. Notably, in support of its conclusion that the federal common law was displaced, the Court relied on Mobil Oil Corp. v. Higginbotham, 436 U.S. 618 (1978), a case we discuss in section II.B infra.

71. 453 U.S. 1 (1981). Other aspects of Sea Clammers are discussed in Sunstein, Section 1983 and the Private Enforcement of Federal Law, 49 U. CHI. L. REv. 394 (1982).

72. See 453 U.S. at 31 (Stevens, J., dissenting).

73. 479 U.S. 481 (1987).

74. Public choice suggests a major risk of rent-seeking legislation by the discharging state, because polluters are likely to be effective lobbyists when their victims are out-of-state. This risk of political favoritism toward local firms is traditionally a rationale for federal court intervention under the dormant commerce clause. See generally Sunstein, Naked Preferences and the Constitution, 84 COLUM. L. REV. 1689, 1705-08 (1984).

75. Section 510 of the Act provides:

Except as expressly provided in this chapter, nothing in this chapter shall (1) preclude or deny the right of any State or political subdivision thereof or interstate agency to adopt or enforce (A) any standard or limitation respecting discharges of pollutants, or (B) any re- 
federal common law of nuisance, but common law cases can still be heard in diversity by federal courts sitting in the receiving state, provided that the nuisance law of the discharging state is applied.

Applying the New Public Law might have benefited the analysis of the Milwaukee II Court. In a sense, the Court attributed both too much to the statute and too little. To the extent that the Court regarded the statute as a complete legislative resolution of all the competing interests, the Court attributed too much comprehensiveness to the legislature. Public choice teaches that a statute reflects not only the preferences of the legislature, but also the procedural obstacle course of enactment. ${ }^{76}$ The fact that a statute explicitly regulates situations $A$ and $B$, but not $C$, should not necessarily be interpreted as a decision to immunize $C$ from regulation. It may only indicate that, for whatever reason, the legislative process failed to produce a bill covering $C$. Thus, the meandering boundaries of a statute may reflect only the exigencies of the legislative process rather than any majority view about the treatment of excluded cases.

In another sense, the Milwaukee II Court attributed too little to the legislature. In Milwaukee $I$, the Court viewed federal pollution legislation not only as a collection of specific regulations, but as embodying a public value. ${ }^{77}$ In Milwaukee II, the Court carefully parsed specific clauses in the statute, finding them not to be decisive. ${ }^{78}$ It ignored, however, the larger message of the statute, which was Congress' deep concern over water pollution. Here, republicanism has a useful message about the legislative role in articulating public values. ${ }^{79}$ Congress' strong endorsement of environmental values should have reinforced the Court's own support for those values. It is deeply ironic

quirement respecting control or abatement of pollution; except that if a [federal requirement] is in effect under this chapter, such State or political subdivision or interstate agency may not adopt or enforce any [requirement] which is less stringent ...; or (2) be construed as impairing or in any manner affecting any right or jurisdiction of the States with respect to the waters (including boundary waters) of such States.

33 U.S.C. $\S 1370$ (1988). A contrary ruling in Ouellette would also have left pollution victims without any damage remedy, because the Clean Water Act provides none. It seems doubtful indeed that Congress intended such a result. Cf. Silkwood v. Kerr-McGee Corp., 464 U.S. 238, 251 (1984).

76. See supra text accompanying notes 31-32.

77. Milwaukee I, 406 U.S. at 101-02 (noting the broad environmental goals of federal pollution legislation).

78. 451 U.S. at 327-29.

79. See, e.g., Eskridge, Public Values in Statutory Interpretation, 137 U. PA. L. REv. 1007, 1009 (1989) (discussing "the substantial role public values already play in statutory interpretation, the potential role they might play, and the values that ought to be considered"); Sunstein, Interpreting Statutes in the Regulatory State, 103 HARV. L. REV. 405, 413 (1989) (describing and defending normative principles to guide statutory interpretation). 
that the Court took a legislative endorsement of environmentalism as a message for judges to withdraw common law restrictions on pollution.

We are sympathetic to the concerns animating the Milwaukee II opinion. Courts need to be aware of their limited ability to deal with technical environmental issues. Courts also need to be sensitive to the danger that common law doctrines can undermine legislative policy judgments. ${ }^{80}$ Nevertheless, Milwaukee $I I$ simply fails to serve these policies effectively, or any others that we can think of.

The Court observed that, since Erie, there is no general federal common law. ${ }^{81}$ The Milwaukee II Court seems to view this doctrine as reflecting an allocation of authority between the federal courts and Congress. But Erie plainly rests on federalism rather than on any protection of federal prerogatives, as shown by the Erie Court's suggestion that the Rules of Decision Act would be unconstitutional if construed to authorize the application of federal common law in diversity cases. ${ }^{82}$ Thus, Erie has little to do with the concerns about legislative supremacy animating Milwaukee II. ${ }^{83}$ In any event, the decision in Milwaukee $I I$ actually disserved both the values of federalism and legislative supremacy.

With regard to federalism, the doctrine derived under Milwaukee $I I$ derogates from the receiving state's quasi-sovereign interest in the integrity of its air and water, recognized in Milwaukee $I$ and Tennessee Copper. ${ }^{84}$ Rather than retaining the ability to apply its own law, or the neutral rules of the federal common law, the receiving state is forced to rely on whatever relief the rules of the discharging state might provide. ${ }^{85}$ Indeed, Ouellette manages to offend even the discharging state's autonomy: in a footnote, the Court stated that the discharging state's nuisance law must be applied even if that state's

80. For example, the tradition of equitable discretion can undermine the policy judgments embodied in modern environmental statutes. Ironically, in light of his opinion in Milwaukee II, Chief Justice Rehnquist has been insensitive to this problem. See Tennessee Valley Authority v. Hill, 437 U.S. 153, 211-13 (1978) (Rehnquist, J., dissenting) (arguing that despite finding a violation of the Endangered Species Act, the district court could, in the exercise of its equitable discretion, refuse to enjoin completion of the Tellico Dam). See generally Farber, Equitable Discretion, Legal Duties, and Environmental Injunctions, 45 U. PITT. L. REV. 513 (1984).

81. 451 U.S. at 312-13.

82. See Westen \& Lehman, Is There Life for Erie After the Death of Diversity?, $78 \mathrm{MrCH}$. L. REV. 311,338 (1980). (1985).

83. See Merrill, The Common Law Powers of Federal Courts, 52 U. CHI. L. REv. 1, 13

84. See supra text accompanying notes 61-64.

85. Despite some contrary dicta in Ouellette, the Tenth Circuit has recently held that the receiving state can have its water-quality standards incorporated into the discharge permit. Oklahoma v. EPA, 908 F.2d 595, 607-08 (10th Cir. 1990). If this decision stands, it will partially mitigate Ouellette's injury to federalism values. 
own choice of law rules point elsewhere. ${ }^{86}$ Thus, Milwaukee II has hardly been a victory for "state's rights."

Milwaukee II is also indefensible from the perspective of legislative supremacy. The Court failed to point to any statutory language or legislative history showing hostility to the federal common law of nuisance. What evidence does exist, such as the savings clause for state laws, shows that Congress intended to supplement rather than displace other remedies for pollution. ${ }^{87}$ Furthermore, the Court's claim that its holding will assist in implementing the statutory scheme is contrary to the view of environmental law experts, ${ }^{88}$ and is belied by the fact that the Environmental Protection Agency and the Department of Justice urged continued acceptance of the federal common law. ${ }^{89}$

Milwaukee II might have been defended for at least reducing the federal court caseload and for taking judgments about pollution law away from federal judges in favor of expert agencies. But Ouellette eliminates these defenses. After Ouellette, most interstate pollution suits can still be brought in federal court as diversity cases, and federal judges will then be making policy judgments (under state law standards) about the proper remedies against polluters. The only difference Milwaukee $I I$ has made is that such cases will not be decided under a uniform and neutral body of law, but instead under fifty separate versions of nuisance doctrine. 90

This is not to say that, in deciding the Milwaukee case, the Court should have ignored the Clean Water Act. Indeed, the Seventh Circuit's decision, which was reversed in Milwaukee II, demonstrates how judges can harmonize the common law with a complex statutory scheme. Judge Tone's opinion for the Court of Appeals repeatedly turned to the federal regulatory scheme as a source of guidance. In Judge Tone's view, the statute implied the undesirability of discharging untreated sewage, ${ }^{91}$ and the EPA regulations indicated a presumptive balance between cost and water quality needs. ${ }^{92}$ In short, Judge Tone used the statute in republican fashion as a source of public val-

86. 479 U.S. at 499 n.20.

87. For a fuller discussion, see 451 U.S. at 339-47 (Blackmun, J., dissenting).

88. See F. Anderson, D. Mandelker \& A. Tarlock, Environmental Protection 758-59 (2d ed. 1990) (quoting Hearings on S.777 and S.2652 before the Senate Subcommittee on Environmental Pollution, 97th Cong., 2d Sess. 654-55 (1982)).

89. 451 U.S. at 346-47 (Blackmun, J., dissenting).

90. Although the common law probably does not vary dramatically between states, Ouellette gives states an incentive to pass statutes protecting local dischargers from suit. See supra note 74.

91. Illinois v. City of Milwaukee, 599 F.2d 151, 170-72 (1979).

92. $599 \mathrm{~F} .2 \mathrm{~d}$ at $173-75$. 
ues. ${ }^{93}$ In our view, by doing so, the Seventh Circuit showed more respect for the legislature's policymaking than did the Supreme Court's formalist bow toward legislative supremacy.

The lesson of Milwaukee $I I$ is that policymaking is not a zero-sum game, as Justice Rehnquist's opinion in Milwaukee II seems to contemplate. A decrease in the role of the federal judiciary is not necessarily a victory for congressional prerogatives. ${ }^{94}$ Because it conceived of federal common law only as a competitor with legislation, Milwaukee II missed the opportunity for beneficial cooperation between legislators and common law judges. A touch of republican dialogue between Congress and the Court would have been far more productive.

The fundamental flaw in Justice Rehnquist's opinion may be a lack of what Karl Llewellyn called "situation sense" - the ability to grasp the essential policy contours of a fact situation. ${ }^{95}$ Rehnquist grasped the right policies; he simply applied them in the wrong case. Practical reason involves the ability to move from the general to the particular. Without it, general theories remain sterile and unhelpful in deciding cases.

\section{B. Common Law Reform}

In Milwaukee II, the Court beat a hurried retreat from its prior common law role in the face of a legislative presence. A more common response to a partial legislative reform had been to freeze the common law, deferring further reform efforts to the legislature. ${ }^{96}$ On the other hand, some courts have proceeded despite - or even because of - a legislative effort to address part of the problem.

The possibilities for common law creativity in a largely statutory setting are illustrated by Moragne v. States Marine Lines, Inc. ${ }^{97}$ Un-

93. Judge Tone stated:

A statute that does not by its terms govern the case before a court may contain indications of the legislature's judgment on relevant issues of policy or provide an appropriate principle for decision of the case. In applying the federal common law of nuisance in a water pollution case, a court should not ignore the Act but should look to its policies and principles for guidance.

599 F.2d at 164 (footnote omitted).

94. Nor is it even necessarily a victory for the collective prerogatives of the states, as we saw earlier. See supra text accompanying notes 84-86.

95. See K. Llewellyn, The Common law Tradition: Deciding appeals 268-85 (1960).

96. See Williams, Statutes as Sources of Law Beyond Their Terms in Common-Law Cases, 50 GEO. WASH. L. REV. 554, 563-70 (1982).

97. 398 U.S. 375 (1970). Although no doubt to many scholars Moragne is just some obscure admiralty case, the problems it illustrates, and the quality of Justice Harlan's opinion in the case, have interested many scholars concerned with the relationship between the common law and 
derstanding Moragne requires a brief review of the history of personal injury law. Under British tort law, transplanted to America, there was no cause of action for wrongful death. ${ }^{98}$ Accordingly, it was considerably wiser - or at least, more profitable - to kill people than to maim them. In the nineteenth century, American state legislatures abolished this absurd rule by establishing statutory rights to sue for wrongful death. ${ }^{99}$ For wrongful deaths of seaworkers, Congress also enacted remedial legislation in 1920 . The Jones Act ${ }^{100}$ provides a cause of action for the negligent death of a seaman, and the federal Death on the High Seas Act ${ }^{101}$ (DOHSA) establishes a cause of action for wrongful death of workers on the high seas - outside the territorial waters of the United States - "caused by wrongful act, neglect, or default."

To simplify somewhat, in Moragne a widow attempted to bring an action for the wrongful death of her husband, who had died from injuries suffered in American territorial waters. Her claim was that the vessel was "unseaworthy," and the common law recognized a well established cause of action for injuries that result from such conditions. ${ }^{102}$ Her claim did not fit the federal wrongful death statutes, however. The Jones Act reaches wrongful death in the territorial waters, but it is limited to negligence claims; ${ }^{103}$ DOHSA encompasses unseaworthiness actions, but reaches only wrongful death on the high seas. $^{104}$ In short, Ms. Moragne had fallen into a hole in the statutes due to the combination of the nature of the wrongful conduct and the place of the accident. The only other law to apply, federal maritime common law, would preclude her action as well, because of the old rule against recovery for wrongful death.

What was obviously needed in Moragne was some way to update

legislation. See, e.g., G. CALABresi, A COMmON LAW FOR THE AGE OF STATUTES 150-59 (1982); W. EsKridge \& P. Frickey, supra note 1, at 247-63; G. GILMORE \& C. BLACK, ThE LAW OF ADMmRalTy 367-74 (2d ed. 1975); Weisberg, The Calabresian Judicial Artist: Statutes and the New Legal Process, 35 STAN. L. REv. 213, 254-56 (1983); Williams, supra note 96, at 561-62, 564-65; Note, The Legitimacy of Civil Law Reasoning in the Common Law: Justice Harlan's Contribution, 82 YALE L.J. 258 (1972). But cf. Posner, Legal Formalism, Legal Realism, and the Interpretation of Statutes and the Constitution, 37 CASE W. RES. L. REV. 179, 201 03 (1986) (questioning analysis in Moragne).

98. See Prosser \& KeEton ON TORTS, supra note $2, \S 125 \mathrm{~A}$, at 940-42.

99. Id.

100. Pub. L. No. 97-389, 96 Stat. 1955 (1982) (codified at 46 U.S.C. app. $\S 688$ (1988)).

101. Death on the High Seas Act, ch. 111, 41 Stat. 537 (1920) (codified as amended at 46 U.S.C. app. $\$ \S 761-68(1988))$.

102. 398 U.S. at 376.

103. See 46 U.S.C. app. $\$ 688$ (a) (1988) (incorporating by reference negligence cause of action in 45 U.S.C. $\$ 51$ ). Also, the Jones Act provides relief only for "seamen," 46 U.S.C. app. § 688(a) (1988), and Mr. Moragne was a longshoreman.

104. See 46 U.S.C. app. $\S 761$ (1988). 
federal law. The statutory language was not easily amenable to any construction that would allow her recovery. The more obvious solution was to abandon the old common law rule, which the Supreme Court did in Moragne in a well-crafted opinion by Justice Harlan. ${ }^{105}$ Justice Harlan concluded that Congress in 1920 was simply fixing the problems squarely presented to it, not comprehensively addressing - and thus freezing - an entire area of law. ${ }^{106}$ Drawing not only from the federal maritime statutes but also from the consistent pattern of state statutes, Justice Harlan found a well-established public value in favor of recovery for wrongful death. Although Justice Harlan had probably never heard of civic republicanism, his decision combined high judicial craftsmanship with republican attention to the legislature's role in articulating public values. ${ }^{107}$

105. In jettisoning the old common law rule, Justice Harlan in Moragne was required to overrule an aged precedent, The Harrisburg, 119 U.S. 199 (1886). His opinion in Moragne contains one of the Court's most thoughtful expressions of the role of stare decisis and its appropriate limitations. See 398 U.S. at 403-05.

Recently, Lawrence Marshall proposed a seemingly absolute rule of stare decisis not only for the Court's statutory interpretation opinions, but also for its federal common law decisions. See Marshall, "Let Congress Do It": The Case for an Absolute Rule of Statutory Stare Decisis, 88 Mich. L. REV. 177, 222 (1989). Marshall justified his view about the federal common law by suggesting that "[i]t is surely not unrealistic to expect Congress to monitor the handful of federal common-law decisions the Supreme Court issues each year." Id. at 222 n.210. For reasons illuminated by public choice theory, see infra note 113 and accompanying text, it is Marshall's proposal that seems unrealistic in the context of Moragne. Moreover, if Congress monitors only the Court's current decisions, it will be left unaware of derelicts like The Harrisburg. (After all, if the Court followed an absolute rule of stare decisis, it would have had no reason to grant certiorari in Moragne.) For another response to Marshall's proposal, and Marshall's reply to the criticism, see Eskridge, The Case of the Amorous Defendant: Criticizing Absolute Stare Decisis for Statutory Cases, 88 Mich. L. Rev. 2450 (1990); Marshall, Contempt of Congress: A Reply to the Critics of An Absolute Rule of Statutory Stare Decisis, 88 MICH. L. REV. 2467 (1990).

106. In considering the potential negative implications of the DOHSA, Justice Harlan thoroughly reviewed the legislative history and concluded:

Read in light of the state of maritime law in 1920, we believe this legislative history indicates that Congress intended to ensure the continued availability of a remedy, historically provided by the States, for deaths in territorial waters; its failure to extend the Act to cover such deaths primarily reflected the lack of necessity for coverage by a federal statute, rather than an affirmative desire to insulate such deaths from the benefits of any federal remedy that might be available independently of the Act. The void that existed in maritime law up until 1920 was the absence of any remedy for wrongful death on the high seas. Congress, in acting to fill that void, legislated only to the three-mile limit because that was the extent of the problem. The express provision that state remedies in territorial waters were not disturbed by the Act ensured that Congress' solution of one problem would not create another by inviting the courts to find that the Act pre-empted the entire field, destroying the state remedies that had previously existed.

398 U.S. at 397-98 (footnote omitted). We see no indication that Congress was concerned about preserving the prerogative of the state to deny relief as a matter of federalism - particularly given that the causes of action for death in territorial waters remain federal.

107. In concluding that the federal and state wrongful death statutes contained a public value that should be borrowed for updating the common law, Justice Harlan drew upon commentaries by Roscoe Pound and James Landis. See 398 U.S. at 391-92 (relying upon Landis, Statutes and the Sources of Law, in HARVARD Legal Essays 213, 226-27 (1934); Pound, Comments on Recent Important Admiralty Cases, 13 NACAA L.J. 162, 188-89 (1954)). Other venerable and valuable discussions are Gellhorn, Contracts and Public Policy, 35 Colum. L. REv. 679, 
This interpretation is not the only possible reading of Moragne. The opinion can also be read, as Judge Posner reads it, ${ }^{108}$ in a more purist "legal process" mode. On this reading, the opinion is primarily motivated by a concern for the "neutral principle" of legal coherence; under this view, Harlan's primary concern is eliminating a legal anomaly. While not without support, however, this interpretation is belied by the structure of the opinion. Harlan begins by rejecting The Harrisburg's preclusion of wrongful death recoveries as normatively untenable. He only then turns to "legal process" issues like coherence in a defensive posture, to determine whether the normatively attractive result is blocked by process arguments.

The Moragne setting also illuminates how public choice can provide insights for the judicial role in common law cases. The interest groups lobbying for statutes like the Jones Act and DOHSA are likely to focus on particular problems, not system-wide inquiries that may complicate passage of legislation. The failure of the various statutes to reach the precise situation of Ms. Moragne carries no plausible implication of a congressional desire to leave her remediless: it is hard to imagine that the deal underlying this series of statutes was to compensate the families of all victims of tortious conduct except those who were killed within three miles offshore of certain states. Thus, public choice warns against reading negative implications into the precise contours of the complicated statutory scheme.

In Moragne, Justice Harlan overtly shaded the inquiry whether a congressional deal precluded adoption of republican values. He noted that legislation sometimes embodies general public policies that courts should apply beyond the statute's domain - the republican insight and at other times reflects hard-fought compromises between conflicting interests that should not be undone by judicial elaboration - the public choice perspective. ${ }^{109}$ Based on the existence of the Jones Act,

690-93 (1935); Pound, Common Law and Legislation, 21 HARV. L. REv. 383 (1908); and Stone, The Common Law in the United States, 50 HARv. L. Rev. 4, 12-13 (1936).

108. See Posner, supra note 97, at 201-03.

109. Justice Harlan wrote:

The legislature does not, of course, merely enact general policies. By the terms of a statute, it also indicates its conception of the sphere within which the policy is to have effect. In many cases the scope of a statute may reflect nothing more than the dimensions of the particular problem that came to the attention of the legislature, inviting the conclusion that the legislative policy is equally applicable to other situations in which the mischief is identical. This conclusion is reinforced where there exists not one enactment but a course of legislation dealing with a series of situations, and where the generality of the underlying principle is attested by the legislation of other jurisdictions. On the other hand, the legislature may, in order to promote other, conflicting interests, prescribe with particularity the compass of the legislative aim, erecting a strong inference that territories beyond the boundaries so drawn are not to feel the impact of the new legislative dispensation.

398 U.S. at 392 (citation omitted). 
DOHSA, and a variety of nonmaritime federal wrongful death statutes, he concluded that "Congress has established a policy favoring recovery in the absence of a legislative direction to except a particular class of cases." 110 He then framed the essential issue in Moragne as whether "Congress has given [any] affirmative indication of an intent to preclude the judicial allowance of a remedy for wrongful death to persons in the situation of this petitioner."111 In essence, Justice Harlan presumed the appropriateness of the republican outcome absent a clear statement by Congress. This tactic, usually found in a variety of "public law" cases, 112 places the heavy burden of legislative silence on the "nonrepublican" side of the case.

Like republicanism, public choice also has some implications about the proper placement of the burden of legislative inertia. Ms. Moragne and similarly situated persons have no idea that they are without remedy until they suffer the loss of a loved one; they have no incentive to organize before the fact to lobby for remedial legislation. Such large, diffuse, unorganized groups are, according to public choice, the least likely to lobby successfully for legislative action. Unions may provide a mechanism for overcoming this collective action problem in some contexts. Even within the union membership, however, this group likely is too inchoate to carry any weight. The nature of the defendants in a case like Moragne provides a stark contrast. Shipping companies have the problem of compensating work-related injuries every day, in contrast to the one-time tragedy suffered by Ms. Moragne. These companies are small in number, easily identified, and have the resources to lobby Congress - public choice predicts that they can organize and protect themselves in the legislative arena. The industry, in short, is well positioned to obtain congressional relief from any harshness resulting from the application of Moragne to future injuries; the Ms. Moragnes of the world are unlikely to obtain legislative relief before their respective losses occur. ${ }^{113}$

110. 398 U.S. at 393.

111. 398 U.S. at 393 (emphasis added).

112. See Eskridge, supra note 69, at 1045-49; Frickey, Congressional Intent, Practical Reasoning, and the Dynamic Nature of Federal Indian Law, 78 CALIF. L. REv. 1139 (1990); Sunstein, supra note 69 , at 471 .

113. A more recent decision is considerably less adept. In Boyle v. United Technologies Corp., 487 U.S. 500 (1988), a military supplier was sued after a marine was killed in the crash of a defective helicopter. Over a strong dissent, the Court established a new federal defense for military contractors, freeing them from liability so long as they warned the government about product defects. 487 U.S. at 512. This was a dramatic expansion in the federal common law, undertaken without regard to the serious concerns about judicial policymaking voiced in Milwaukee II. As the dissent pointed out, government contractors had conducted a vigorous but unsuccessful lobbying campaign to get this exemption from Congress. 487 U.S. at 515, n.1 (Brennan, J., dissenting). Public choice suggests that the burden of legislative inertia would have 
Following Moragne, the Supreme Court engaged in a tortuous effort to fit the common law cause of action for wrongful death resulting from unseaworthiness within the broader framework of the maritime statutes. In Sea-Land Services v. Gaudet, ${ }^{114}$ a sharply divided Court held that, because the Moragne cause of action was common law in nature, modern common law rules defining damages recoverable should apply; recovery could thus include certain nonpecuniary losses such as loss of society. In Mobil Oil Corp. v. Higginbotham, ${ }^{115}$ however, the Court confined the Moragne cause of action to territorial waters - thereby relegating the surviving spouse of a seaworker killed on the high seas to damages only as provided for in DOHSA, which explicitly limits recovery to pecuniary loss. ${ }^{116}$ Most recently, in Miles $v$. Apex Marine Corp., ${ }^{117}$ the Court held that damages for wrongful loss of society cannot be recovered in a Moragne action brought on behalf of a seaman, ${ }^{118}$ limiting Gaudet to actions for injuries to longshoremen in territorial waters - a limitation that leaves Gaudet little or no practical application. ${ }^{119}$

Formalistically, the post-Moragne cases make some sense. In Gaudet no statute applied, and so (modern) common law principles controlled; in Higginbotham and Miles, DOHSA or the Jones Act applied, and thus plaintiff was stuck with the (arguably obsolescent) recovery provided in those statutes. After the two most recent decisions, Moragne essentially does little more than eliminate the phrase "high seas" from the title of DOHSA, extending the statutory remedy landward. The policy of uniformity, which was one of the Moragne Court's concerns, has been fully served, 120 but at the expense of the Moragne Court's even stronger desire to provide a just remedy for the survivors of maritime workers.

been properly placed on these firms, which are well-organized, politically powerful, and wealthy. Unfortunately, the Court instead placed the burden of seeking new legislation on the widows and orphans of soldiers.

114. 414 U.S. 573 (1974).

115. 436 U.S. 618 (1978).

116. See 46 U.S.C. app. $\$ 762$ (1988) ("a fair and just compensation for the pecuniary loss sustained by the persons for whose benefit the suit is brought") (emphasis added).

117. 111 S. Ct. 317 (1990).

118. $111 \mathrm{~S}$. Ct. at 326. A second holding in Miles, which we will not discuss, limits the recovery of lost earnings in maritime wrongful death actions. See $111 \mathrm{~S}$. Ct. at 326-28.

119. $111 \mathrm{~S}$. Ct. at 325. As the Court notes elsewhere in its opinion, unseaworthiness actions may no longer be brought by longshoremen because of a 1972 statute, which created a different compensation scheme for these workers. $111 \mathrm{~S}$. Ct. at 323 . Consequently, Gaudet seems not to apply under any circumstances at all.

120. As the Miles Court observed, its decision eliminated the disparity created by Gaudet and Higginbotham between the measure of damages for wrongful death on the high seas and that in territorial waters. $11 \mathrm{~S}$. Ct. at 326. 
A brief evaluation of the post-Moragne cases from the perspective of the New Public Law is illuminating. Moragne relied upon republican principles - that the common law of torts presumptively embodies modern public values, including recovery for wrongful death. Gaudet stressed this same factor in following the "clear majority of States"121 and "the humanitarian policy of the maritime law to show 'special solicitude' for those who are injured within its jurisdiction."122 The dissenters in Gaudet saw Moragne much differently, as simply a gap-filling decision where the precise contours of DOHSA were adopted by analogy to the common law. ${ }^{123}$ In essence, the dispute in Gaudet was between finding a republican concept in DOHSA to be elaborated upon in defining the modern common law and finding a congressional conception of the appropriate rule of law that, even if outdated, should be applied to promote legal uniformity. The Gaudet dissenters' position is inconsistent with Moragne's public choice insights - that the political dynamics surrounding passage of the Jones Act and DOHSA indicate no congressional intent to prescribe fixed rules for all wrongful deaths on the waters.

Higginbotham is a harder case because DOHSA squarely applied and provided only for recovery of pecuniary loss. Allowing the plaintiff to recover nonpecuniary loss might seem equivalent to Guido Calabresi's proposal that judges simply discard statutes because they have lost majority support or are incompatible with the legal landscape. ${ }^{124}$ Although we have serious qualms about Calabresi's approach, ${ }^{125}$ we doubt that one need go so far to support the conclusion that Higginbotham is at least questionable.

Higginbotham concluded that the Court need not engage in republican inquiries about public values because "Congress has struck the balance for us."126 At most, however, the principle of legislative supremacy is violated only when a court refuses to follow a clear legislative command. ${ }^{127}$ Higginbotham assumed that such a command was

121. 414 U.S. at 587.

122. 414 U.S. at 588.

123. See 414 U.S. at 596 (Powell, J., dissenting).

124. See G. CALABRESI, supra note 97, at 148.

125. See D. FARBER \& P. FRICKEY, supra note 8, at 106-08.

126. 436 U.S. at 623.

127. See Farber, supra note 56, at 282; Eskridge, supra note 39, at 1496-97, 1542-44. We say "at most" because while that is the view of one of us, the other has waffled on this point. See Frickey, supra note 112, at 1213-17. Although we pretty much agree on the principle, we might disagree in some cases whether there is a legislative "command," and if there is one whether there has been a clear violation of it. Also, even the Farber view leaves some room for maneuver in the face of changed circumstances. See Farber, supra note 56, at 307-09. 
present in DOHSA, but that conclusion is at least overstated, if not wrong.

First, the statutory language at issue granted a "fair and just compensation for the pecuniary loss sustained."128 Nowhere does it say that nonpecuniary loss cannot be recovered. The majority's conclusion that this section reflected Congress" "considered judgment" 129 to reject nonpecuniary damages is unsupported by reference to any legislative history. Indeed, the legislative history of DOHSA, as interpreted in Moragne, suggests that Congress had simply fixed some particular problems brought before it by incorporating the tort values of the era, not necessarily freezing the law to reflect forevermore the 1920 s conceptions of how to implement those values. ${ }^{130}$ In this respect, the majority's statement in Higginbotham that "[t]here is a basic difference between filling a gap left by Congress' silence and rewriting rules that Congress has affirmatively and specifically enacted"131 seems defensible but also somewhat attenuated. In all events, it conflicts with Justice Harlan's conclusion in Moragne that "no intention appears that the Act have the effect of foreclosing any nonstatutory federal remedies that might be found appropriate to effectuate the policies of general maritime law." 132

In short, Moragne and Gaudet saw our "general law" — DOHSA, state wrongful death statutes, and current values - as promoting a case-by-case search for solutions that best effectuate the humanitarian policies of the maritime law. In. contrast, Higginbotham treated DOHSA like a bill of lading. For us, the appropriate resolution of Higginbotham should have turned on a republican evaluation of the policies at issue (for example, is recovery of nonpecuniary loss really necessary to effectuate modern humanitarian policies?) and a public choice inquiry into the "deal" - if any — struck in the 1920 Congress. If the outcome in Higginbotham is correct, it is not for the reasons expressed by the majority. ${ }^{133}$

\footnotetext{
128. 46 U.S.C. app. $§ 762$ (1988).

129. 436 U.S. at 624.

130. See 398 U.S. at $397-402$.

131. 436 U.S. at 625.

132. 398 U.S. at 400 .
}

133. Indeed, the plausibility of a contrary outcome in Higginbotham is suggested by the sensible opinion of the Supreme Court of Nebraska in a somewhat similar case. In Selders v. Armentrout, 190 Neb. 275, 277, 207 N.W.2d 686, 687 (1973), the Nebraska court allowed parents to recover nonpecuniary loss for the wrongful death of a minor child under a wrongful death statute that provided that the "avails of" the wrongful death action "shall be paid to and distributed among the widow or widower and next of kin in the proportion that the pecuniary loss suffered by each bears to the total pecuniary loss suffered by all such persons." The majority explained that the full language of the statute did not compel any limitation of recovery to pecuniary loss: the wrongful death cause of action was for "damages," not "pecuniary damages," and 
Miles completed the Court's retreat from the creative judicial role contemplated by Moragne. The Miles Court held that damages for loss of society are unavailable in a Moragne action because such damages are unavailable under the Jones Act. It would be "inconsistent with our place in the constitutional scheme were we to sanction more expansive remedies in a judicially-created cause of action in which liability is without fault than Congress has allowed in cases of death resulting from negligence." 134 A close reading of the opinion suggests, however, that this judicial modesty is misplaced. If Congress had rejected nonpecuniary damages in the Jones Act, perhaps there would be some basis for judicial deference in fashioning the common law remedy. In reality, however, there was no legislative decision to which to defer.

The Jones Act itself contains no limitation on the types of damages recoverable. It borrowed its language from the FELA, which provided a federal remedy for injuries to railroad workers. The FELA also contained no express limitation on damages, but the Supreme Court read such a limitation into the FELA in 1913.135 It was this decision that formed the basis for the ruling in Miles. Since Congress said nothing to the contrary, according to the Miles Court, it "must have intended" to incorporate this judicial gloss when it passed the Jones Act. ${ }^{136}$ In short, what the Court proclaims as judicial deference to the legislature, turns out really to be the 1990 Court's deference to a decision by the 1913 Court under a different statute. Congress is "assumed" to have agreed with the 1913 Court, ${ }^{137}$ so the current Court

that the provision above simply governed the apportionment of damages, not the amount that could be recovered. $207 \mathrm{Neb}$. at 277,207 N.W.2d at $687-88$. To rebut the obvious in pari materia argument that the recovery and apportionment provisions should be interpreted identically, the majority stressed republican values - the modern humanitarian trend toward recovery of nonpecuniary loss, especially where a minor child's death is involved (lest there be no recovery available at all). The court also pointed out that its precedents, not the statute, were the only crystal-clear sources of positive law in the state limiting recovery to pecuniary loss. $207 \mathrm{Neb}$. at 279,207 N.W.2d at 689 . In overruling those precedents, the court could have made a useful point suggested by public choice: the legislature had inserted "pecuniary" into the statute in 1945, and may well have simply been reflecting what the court had said about the statute rather than making any policy judgment about the recovery of nonpecuniary loss. $C f$. Li v. Yellow Cab Co., 13 Cal. 3d 804, 532 P.2d 1226, 119 Cal. Rptr. 858 (1975) ("updating" construction of state negligence statute to incorporate comparative negligence scheme). In $L i$, the statutory language did not forbid the updating and the legislature that adopted the statute, while apparently assuming that contributory negligence would be the law, seemed to be simply incorporating then-current tort approach rather than intending to freeze tort law from future developments. We suspect the same was true of DOHSA.

134. $111 \mathrm{~S}$. Ct. at 326.

135. See Michigan Cent. R.R. v. Vreeland, 227 U.S. 59, 68 (1913).

136. $111 \mathrm{~S}$. Ct. at 325.

137. "We assume that Congress is aware of existing law when it passes legislation." $111 \mathrm{~S}$. Ct. at 325. 
would be exceeding its constitutional role were it to adopt a different rule - not under the FELA, which was the subject of the 1913 decision, nor under the Jones Act, which is presumed to have endorsed the 1913 decision, but under the federal common law created by Moragne, which neither the two earlier statutes nor the 1913 decision had foreseen. This conclusion was especially ironic because Moragne was based on a rejection of the grudging attitude toward wrongful death actions encompassed in the 1913 decision itself. ${ }^{138}$

The Miles Court claimed that its decision was controlled by " $[t]$ he logic of Higginbotham" and that in Higginbotham "Congress made the decision for us." 139 As we have seen, even with repect to Higginbotham this is a questionable assertion. It turns out, however, that Congress had never enacted any statutory language bearing in any way on the issue in Miles. The only actual decision was made by the Court itself in 1913; everything else is presumed from congressional silence. Deference to a legislative decision is all very well and good, but it is quite another thing to posit a fictional legislative decision first and then "deferentially" extend that fictional decision into a common law domain. In the end, the Miles Court's exercise in deference was little more than an excuse to avoid responsibility for its own decision.

This is not to say that courts should always be in the forefront of law reform. When a court is asked to make a policy judgment, either at the microlevel as in Milwaukee II or at the law-reform level as in Moragne, there may be good reason to decline. The court may simply be too uncertain of the right answer to intervene, preferring to leave the issue to bodies with greater expertise or popular accountability. Sometimes the best solution will exceed a court's remedial powers, for example, by requiring a new set of highly integrated rules that do not lend themselves to common law evolution, or by requiring the creation of an administrative agency. In addition, in some circumstances there may be good reason to believe that the legislature approves of the existing rule. Finally, the group adversely affected by a proposed change in rules may be very poorly situated to obtain legislative relief, and the

138. The Vreeland Court went out of its way to recall the common law's hostility to wrongful death actions:

Nothing is better settled than that at common law the right of action for an injury to the person is extinguished by the death of the party injured. ...

At common law loss and damage may, in some cases, accrue to persons dependent upon one wrongfully injured and a right of action in some cases arises in their behalf. But this cause of action, except for loss of personal services, before the death, abates at the death.

In Baker v. Bolton, 1 Campbell, 493, Lord Ellenborough ruled that "in a civil court, the death of a human being could not be complained of as an injury."

227 U.S. at 67-68.

139. $111 \mathrm{~S}$. Ct. at 325. 
court may be reluctant to foreclose legislative consideration of the issue.

Thus, our endorsement of Moragne and condemnation of Milwaukee II and Miles should not be read as support for wide-open common law activism. And indeed, it would be highly peculiar to consider Justice Harlan, author of our paradigm opinion, as a judicial activist. We view the legislature as the senior partner in the joint venture of making public policy. But the courts can do a great deal to further the enterprise, and republicanism and public choice are useful tools in defining the border between judicial and legislative prerogatives. ${ }^{140}$

\section{CONCLUSION}

In the first place, we have tried in this article to debunk the formal categorization of legal problems. In our view, the essential lesson of the "New Public Law" - that political theory (and in particular, postpluralist theory) matters - is applicable as well to the old private law. Although perhaps that point seems obvious, neither "public" law nor "private" law scholars have generally recognized that the age of statutes has modified legal theory across the board. The shadow of the legislature touches the scholar whether or not she is concerned primarily with facilitative or supervening legal rules, statutes or common law.

More particularly, we have attempted to demonstrate that two important political theories of the New Public Law, republicanism and public choice, provide fruitful insights into common law problems. Upon reflection, at least some of this may seem obvious as well. The common law has probably always involved judicial judgments about the ways adjudication can foster the public interest. Republicanism's focus on civic virtue adds something distinctive to this process, however. For example, by emphasizing the legislature's capacity to define public values, it strongly reinforces the borrowing of statutory analogies for common law purposes, as Moragne illustrates. In many instances, the legislature is both more legitimate in theory and more capable in practice of defining public values than are judges. Yet the institutional insulation of judges and the deliberative qualities stressed by republicanism - judicial advantages usually considered only in the

140. Our view - that courts should not unthinkingly refer resolution of an issue to the legislature - can also be supported on more traditional grounds. See H. HART \& A. SACKs, supra note 6, at 543-46. Hart and Sacks, however, are usually seen as somewhat resistant to the concept of the courts as making policy. See id. at 397-98. For a more extensive discussion of Hart and Sacks, and their relation to the New Public Law, see the article by Eskridge and Peller in this Symposium. Eskridge \& Peller, The New Public Law Movement: Moderation as a Postmodern Cultural Form, 89 MrCF. L. REv. 707 (1991). 
public law setting - will sometimes emporwer the common law judge as well to promote legal change in the pursuit of public values. Public choice helps these judges consider the institutional issues that arise in an ever-increasingly interactive world of public policymaking.

It is important, however, not to lose sight of the deeper tension between republicanism and public choice. Ultimately they embody different perspectives on the nature of politics - as one seeks to remind us of its aspirations, the other recalls its flaws and thereby calls those aspirations into question. We doubt if those tensions can ever be fully resolved by incorporating both into some even more abstract Grand Unified Theory of politics. Rather, this tension may well reflect the ultimate moral ambiguity of politics itself. If the phrase were not already taken, ${ }^{141}$ we might speak here of the "fundamental contradiction" of the New Public Law. Such contradictions, we suspect, are an essential source of dynamic tension for law as a living practice, as opposed to law as abstract theory. In any event, no grand synthesis of these two theories is yet available, and legal analysis must proceed in the meantime.

In earlier writings, we have suggested that paradigm cases can often offer more guidance than grand theories. ${ }^{142}$ Justice Harlan's opinion in Moragne, with its sensitivity both to public values and to the limitations of judicial policymaking, would serve well as such a paradigm for common law judges.

If nothing else, we hope to encourage legal scholars of all stripes to take the new normative and empirical theories seriously. By emphasizing the roles these theories can play on a case-by-case basis, we also hope to stimulate their consideration by the practitioners of nonstatutory law reform, judges and litigators. For at bottom, republicanism and public choice are less useful as recipes for new formal theories of public law than as tools for the eclectic process of arguing and deciding hard cases generally. As mainstream public law theory becomes increasingly antiformalist, ${ }^{143}$ it should be unsurprising that the tools it uses have significant potential for common law adjudication.

141. Kennedy, The Structure of Blackstone's Commentaries, 28 Buffalo L. REv. 205, 213 (1979).

142. See Farber \& Frickey, supra note 40, at 1629-39. See also Farber, Legal Pragmatism and the Constitution, 72 MINN. L. REv. 1331, 1334-43 (1988); Frickey, supra note 112, at 1219$20,1223-40$.

143. This point is probably made most vividly in the work of several Critical Legal Scholars. See Feinman, Practical Legal Studies and Critical Legal Studies, 87 Mich. L. REv. 724 (1988); Hutchinson, The Three 'Rs': Reading/Rorty/Radically (Book Review), 103 HARV. L. Rev. 555 (1989); Tushnet, Anti-Formalism in Recent Constitutional Theory, 83 МicH. L. REv. 1502 (1985). 